\title{
Hydrology of inland tropical lowlands: the Kapuas and Mahakam wetlands
}

\author{
Hidayat Hidayat ${ }^{1,2}$, Adriaan J. Teuling ${ }^{1}$, Bart Vermeulen ${ }^{1,7}$, Muh Taufik ${ }^{1,8}$, Karl Kastner ${ }^{1}$, Tjitske J. Geertsema ${ }^{1}$, \\ Dinja C. C. Bol ${ }^{1}$, Dirk H. Hoekman ${ }^{3}$, Gadis Sri Haryani ${ }^{2}$, Henny A. J. Van Lanen ${ }^{1}$, Robert M. Delinom ${ }^{4}$, \\ Roel Dijksma $^{1}$, Gusti Z. Anshari ${ }^{5}$, Nining S. Ningsih ${ }^{6}$, Remko Uijlenhoet ${ }^{1}$, and Antonius J. F. Hoitink ${ }^{1}$ \\ ${ }^{1}$ Hydrology and Quantitative Water Management Group, Wageningen University, Wageningen, the Netherlands \\ ${ }^{2}$ Research Center for Limnology, Indonesian Institute of Sciences, Cibinong, Indonesia \\ ${ }^{3}$ Earth System Science and Climate Change Group, Wageningen University, the Netherlands \\ ${ }^{4}$ Research Center for Geotechnology, Indonesian Institute of Sciences, Bandung, Indonesia \\ ${ }^{5}$ Soil Science Department, Tanjungpura University, Pontianak, Indonesia \\ ${ }^{6}$ Faculty of Earth Sciences and Technology, Bandung Institute of Technology, Bandung, Indonesia \\ ${ }^{7}$ Department of Water Engineering and Management, University of Twente, Enschede, the Netherlands \\ ${ }^{8}$ Department of Geophysics and Meteorology, Bogor Agricultural University, Bogor, Indonesia
}

Correspondence to: Hidayat Hidayat (hidayat@limnologi.lipi.go.id)

Received: 1 August 2016 - Discussion started: 23 August 2016

Revised: 14 March 2017 - Accepted: 25 April 2017 - Published: 24 May 2017

\begin{abstract}
Wetlands are important reservoirs of water, carbon and biodiversity. They are typical landscapes of lowland regions that have high potential for water retention. However, the hydrology of these wetlands in tropical regions is often studied in isolation from the processes taking place at the catchment scale. Our main objective is to study the hydrological dynamics of one of the largest tropical rainforest regions on an island using a combination of satellite remote sensing and novel observations from dedicated field campaigns. This contribution offers a comprehensive analysis of the hydrological dynamics of two neighbouring poorly gauged tropical basins; the Kapuas basin $\left(98700 \mathrm{~km}^{2}\right)$ in West Kalimantan and the Mahakam basin $\left(77100 \mathrm{~km}^{2}\right)$ in East Kalimantan, Indonesia. Both basins are characterised by vast areas of inland lowlands. Hereby, we put specific emphasis on key hydrological variables and indicators such as discharge and flood extent. The hydroclimatological data described herein were obtained during fieldwork campaigns carried out in the Kapuas over the period 2013-2015 and in the Mahakam over the period 2008-2010. Additionally, we used the Tropical Rainfall Measuring Mission (TRMM) rainfall estimates over the period 1998-2015 to analyse the distribution of rainfall and the influence of El-Niño - Southern Oscillation. Flood occurrence maps were obtained from the analysis of the Phase
\end{abstract}

Array type L-band Synthetic Aperture Radar (PALSAR) images from 2007 to 2010. Drought events were derived from time series of simulated groundwater recharge using time series of TRMM rainfall estimates, potential evapotranspiration estimates and the threshold level approach. The Kapuas and the Mahakam lake regions are vast reservoirs of water of about 1000 and $1500 \mathrm{~km}^{2}$ that can store as much as 3 and 6.5 billion $\mathrm{m}^{3}$ of water, respectively. These storage capacity values can be doubled considering the area of flooding under vegetation cover. Discharge time series show that backwater effects are highly influential in the wetland regions, which can be partly explained by inundation dynamics shown by flood occurrence maps obtained from PALSAR images. In contrast to their nature as wetlands, both lowland areas have frequent periods with low soil moisture conditions and low groundwater recharge. The Mahakam wetland area regularly exhibits low groundwater recharge, which may lead to prolonged drought events that can last up to 13 months. It appears that the Mahakam lowland is more vulnerable to hydrological drought, leading to more frequent fire occurrences than in the Kapuas basin. 


\section{Introduction}

Lowland rivers are of major importance for mankind not only due to their extensive uses for many purposes such as food production, drinking water and navigation, but they are also important ecosystems that thrive from a regular supply of nutrients from sediment deposited during floods. Since the very beginning of agricultural activities, most of the worlds' population has been concentrated on fertile alluvial floodplains that support food production as well as access to waterways for transport (Verhoeven and Setter, 2010). Envisioning the fate of lowland rivers and the adjacent wetlands in response to current threats, including those stemming from natural processes as well as those of anthropogenic origin, will likely remain a challenge in the coming years. Measures to mitigate flood, drought and loss of biodiversity add to elements that keep lowland rivers a dynamic theme (Hoitink and Jay, 2016).

Typically, lowlands are located in the downstream part of a river basin in the form of deltas. However there are also lowlands that are located in more upstream parts of the basin. The absence of topographical gradients often leads to the formation of (seasonal) wetlands. The Congo and Amazon are the best known examples of tropical rainforest regions characterised by vast areas of lowlands and wetlands (Hess et al., 2015). Besides permanent open water lakes, the Congo basin contains an extensive wetland system with diffuse water shorelines, which in some areas are inundated under thick vegetation cover, forming one of the largest swamp forest in the world known as the Cuvette Centrale (Alsdorf et al., 2016). However, there is a lack of knowledge regarding processes involved in seasonal flooding in tropical lowland areas. Inundation extent, water depth, groundwater and the storage volume of the wetland are not well known as few hydrological studies have been conducted in this area (Alsdorf et al., 2016). The floodplain of the Amazon River also contains lakes that are temporally or permanently connected to the main river by several channels (Bonnet et al., 2008). Water from the Amazon flows into the floodplain lakes at the beginning of the rising tide, but by mid-level tide, lake water gradually flows out into the river (Lesack and Melack, 1995). Along with these processes, groundwater regulates the seasonal dynamics of the Amazon surface waters (MiguezMacho and Fan, 2012). Hoch et al. (2017) recently assessed the impact of hydrodynamics on flood wave propagation of the Amazon by coupling a global hydrologic model with a hydrodynamic model. They found that, although the coupled runs simulate discharge better than hydrology-only runs, some peak flows are overestimated due to the lack of a feedback loop to hydrological processes on floodplains, such as evaporation and groundwater infiltration.

Although definitions of wetlands are based on hydrologic conditions (Zedler and Kercher, 2005; Verhoeven and Setter, 2010), hydrology is the aspect of wetlands that is the most poorly described due to technical, cost and time con- straints of field measurements in this area (Cole et al., 1997). Determining an average or specific hydroperiod, the period in which a soil area is waterlogged, or on the contrary, a period with below-normal water storage for wetland sites, subsequently remains a major technical challenge. Piezometers are commonly used to analyse water levels in studies at the plot scale in peatlands. However, maintaining them is labour intensive (Devito et al., 1996; Fraser et al., 2001; Baird et al., 2004; Ishii et al., 2015). The application of satellite remote sensing techniques is one approach which addresses this scarcity of information. Data from optical sensors such as Landsat imagery can be used for this purpose in areas with little cloud cover (e.g. Qi et al., 2009; Adam et al., 2010; Ran and Lu, 2012). However, it is hard to satisfy the preferred limit of cloud cover for such images covering the humid tropics. For this reason, radar remote sensing is considered to be the most suitable technique for land and water observation in tropical regions. Hidayat et al. (2012) demonstrate that flood occurrence information and the corresponding extent of open water, as well as areas under vegetation cover, can be extracted from a series of images from the Phase Array type L-band Synthetic Aperture Radar (PALSAR) covering a humid tropical lowland site. Using images from an L-band SAR sensor, Hess et al. (2015) exhibit the capabilities of radar remote sensing technique for mapping tropical wetland extent and inundation over large regions. Other approaches that try to overcome at-site data scarcity involve simulation modelling using large-scale data sets as input (e.g. Van Loon et al., 2012).

Lowland regions are typified by certain hydrological properties, e.g. small hydraulic gradients, shallow groundwater, a flat topography and a high potential for water retaining in wetlands (Schmalz et al., 2008). Intensive groundwater-stream water interactions as well as soil moisture-groundwater interactions occur in these areas as a result of shallow groundwater conditions (Brauer et al., 2014). The hydrology of lowlands is complicated by backwater effects, lake-river interactions, possible tidal effects, hydrological extremes, etc. Backwater effects result in an ambiguous stage-discharge relation (Petersen-Overleir and Reitan, 2009; Herschy, 2009; Hidayat et al., 2011b) such that, at any given discharge, falling river stages are much higher than rising stages. Tides have a significant impact on the river flow farther away from the river mouth in lowland regions by means of subtidal water level variations controlled by rivertide interactions (Buschman et al., 2009; Hoitink and Jay, 2016). Therefore, hydrological tools, such as the use of rating curves, rainfall-runoff models and flood prediction, may fall short if they are applied without a proper adaptation. Novel measurement and modelling methods such as continuous flow measurements (Sassi et al., 2011; Hoitink et al., 2009) and neural networks (Corzo et al., 2009; Hidayat et al., 2014) can be promising means concerning the complex interactions of peat areas, lakes, runoff and tides in this region. Although tropical wetlands are more prone to high water, they 
also regularly suffer from drought (Walsh, 1996). This requires approaches that consider both hydrological extremes.

The Kapuas and Mahakam river basins on Kalimantan represent two large tropical lowland areas. Figure 1 shows the location of the Kapuas (total catchment area of $98700 \mathrm{~km}^{2}$ ) in West Kalimantan and the Mahakam $\left(77100 \mathrm{~km}^{2}\right)$ in East Kalimantan. Both rivers are among the longest rivers worldwide, are found on one island and are characterised by vast areas of inland lowlands. The size of the rivers, the complex geomorphology of their lowland channel networks and the hydrological links with the adjacent peat bogs and inland wetlands, which are prone to drought and forest fires during dry years, render the Kapuas and the Mahakam basins a scientific challenge. The Kapuas and Mahakam rivers exemplify data-poor environments in the tropical region, with catchments that comprise vast areas of rainforest. Few hydrological studies have been conducted in the region despite the rivers' importance to environment and the people. Parts of these catchments can be considered relatively pristine, offering a view of a natural hydrological regime which serves both scientific and engineering purposes. Compared to their mid- and high-latitude counterparts, a few studies have addressed the hydrological dynamics of large tropical rivers. This is mainly caused by the fact that most tropical rivers are poorly gauged. Over the past decade, many hydrological studies have focussed on the problem of ungauged basins under the Prediction in Ungauged Basins initiative (Sivapalan et al., 2003; McGlynn et al., 2013) of the International Association of Hydrological Sciences. Growing international research connections attempt to holistically study the terrestrial system and the development of globally consistent databases, including those from remote sensing observations, climate stations, downscaled bias-corrected output from climate models. This gap is now gradually changing (Syvitski et al., 2014; Harris et al., 2014; Weedon et al., 2011), contributing to this trend. By combining field measurements of key hydrological variables over two large tropical catchments using modelling and different sources of satellite remote sensing, we can quantify flooding both in terms of water level, inundated area and volume, and we reveal the impacts of important processes such as backwater effects.

Our central objective is to study the hydrological dynamics in the Kapuas and Mahakam river basins, located in of one of the largest tropical rainforest regions outside the Congo and Amazon using a combination of satellite remote sensing and novel observations from dedicated field campaigns. Hereby, we put specific emphasis on key hydrological variables and indicators such as discharge and flood extent. Resolving hydrological processes is essential to understand the impact of changes in terrestrial hydrological and biogeochemical cycles including land degradation on water level dynamics, water quality and ecology of these important yet vulnerable wetland regions. The interactions between wetlands and the river have implications for geomorphology, governing sediment retention and modulating peak discharges, and for estuar-

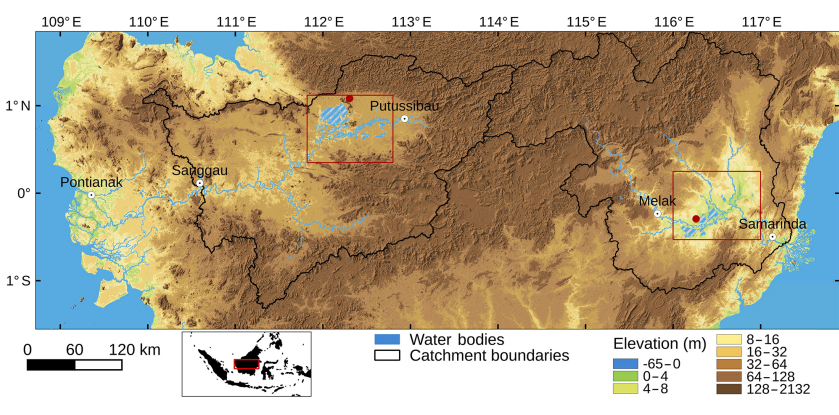

Figure 1. Map of the research area. Outlined are the Kapuas catchment upstream of Sanggau (left) and the Mahakam catchment upstream of its delta region (right), indicated by the black line. Red boxes indicate the focus regions encompassing the Kapuas and Mahakam lowlands. Red circles indicate the locations of point rainfall, soil moisture and groundwater observations. Discharge monitoring stations are located in the city of Sanggau (the Kapuas) and in the city of Melak (the Mahakam).

ine processes, controlling salinity intrusion during low flow. The data set will offer a solid database which will find use in future research and engineering. Section 2 of this paper describes the two study catchments. Section 3 presents field data gathering to measure water levels, soil moisture and discharge. This section also describes satellite-based data that cover the entire catchments and the method used for obtaining inundation maps. Section 4 presents the results in the form of a hydrological comparison between the two lowlands. Section 5 presents the discussion, and conclusions are drawn in Sect. 6.

\section{Study area}

The Kapuas and the Mahakam are the longest and the second longest rivers in Indonesia with lengths of about 1140 and $980 \mathrm{~km}$, respectively. The Kapuas and the Mahakam lowlands are located about 650 and $250 \mathrm{~km}$ from their respective river mouths. Lake Sentarum National Park in the upper Kapuas River is an important Ramsar site, which represents one of old tropical peat formations in Late Pleistocene (Anshari et al., 2001, 2004). The Mahakam River is home to endemic species including the Irrawady dolphin (Orcaella brevirostris), which is listed as "vulnerable" on the International Union for Conservation of Nature (IUCN) Red List of Threatened Species due to entanglement in gillnets, vessel traffic, sedimentation, habitat loss and degradation from habitat change (IUCN, 2016), etc. The Kapuas and the Mahakam wetlands are important for their respective local communities, not only as a source of water for domestic purposes, but also to sustain the livelihoods of people, especially in the open water fishery subsector. The Kapuas wetland with its seasonally inundated lakes produces about 18000 tons of freshwater fish annually (BPS-Kalbar, 2015). The middle Mahakam wetland is the core of inland fisheries 
in East Kalimantan and is considered one of the most productive freshwater fisheries in south-eastern Asia (MacKinnon et al., 1996) with a current estimated annual fish production of 33000 tons (BPS-Kaltim, 2015). These fishing industry figures express the high economic value of the wetland areas we study. The unique tropical wetland ecosystems are rich in biodiversity of typical aquatic as well as terrestrial flora and fauna, which is why they are listed as Ramsar sites and designated for conservation. Notwithstanding their ecological, hydrological and economical importance, the Kapuas and Mahakam wetlands in particular and the two river basins in general have been increasingly threatened by a variety of factors including pollution, forest fires, deforestation and monoculture (Rautner et al., 2005; Chokkalingam et al., 2005).

Both the Kapuas and Mahakam rivers originate from the centre of Borneo on the border between West Kalimantan (Indonesia) and Sarawak (Malaysia). The Kapuas originates from the Kapuas Hulu mountains, runs westward through mountainous terrain and descends into a flat plain (Loh et al., 2012). At this plain, from Putussibau until the delta, the river elevation drops by just $50 \mathrm{~m}$ over a length of $900 \mathrm{~km}$ (MacKinnon et al., 1996). This results in the formation of the Kapuas floodplain lake area in the upstream part of the river. Figure 2 (top pictures) show conditions of the lake area during wet and dry periods. The Kapuas lake area, which includes the Lake Sentarum National Park, is surrounded by mountain ranges; the Upper Kapuas Mountains in the north, the Muller Mountains in the east, the Madi Plateau in the south and the Kelingkang mountains in the west (MacKinnon et al., 1996). Despite its inland position, most of this wetland basin lies less than $30 \mathrm{~m}$ above sea level (Anshari et al., 2004). Downstream of the wetlands, the Kapuas meets a main tributary, the River Melawi, flows further westward through a low mountain land, bifurcates into the Kapuas Besar and the Kapuas Kecil, and finally continues to the Kapuas delta distributaries towards the Karimata Strait. This strait is connected to the South China Sea, which is very busy and important to the livelihoods of communities in south-eastern Asia. The capital of West Kalimantan, Pontianak, which is inhabited by about 600000 people (estimate from 2014; see BPS-Kalbar, 2015), lies right on the equator along the Kapuas Kecil.

The Mahakam flows from its source through the PreTertiary rocks in a south-easterly direction and reaches the Tertiary basin of Kutai. The river then meets the Kedang Pahu River in the middle Mahakam region (Van Bemmelen, 1949). The Mahakam meanders eastward from there through Quarternary alluvium in the Mahakam lake area. This area is a flat tropical lowland region circumscribed by wetlands with seasonal flooding (Fig. 2, bottom left picture). Some 30 shallow lakes, which are connected to the Mahakam through small channels, are situated in this area. The Mahakam meets three other main tributaries downstream of the lake area and flows south-eastward through a Tertiary mountain range before reaching the Mahakam delta distributaries and de-

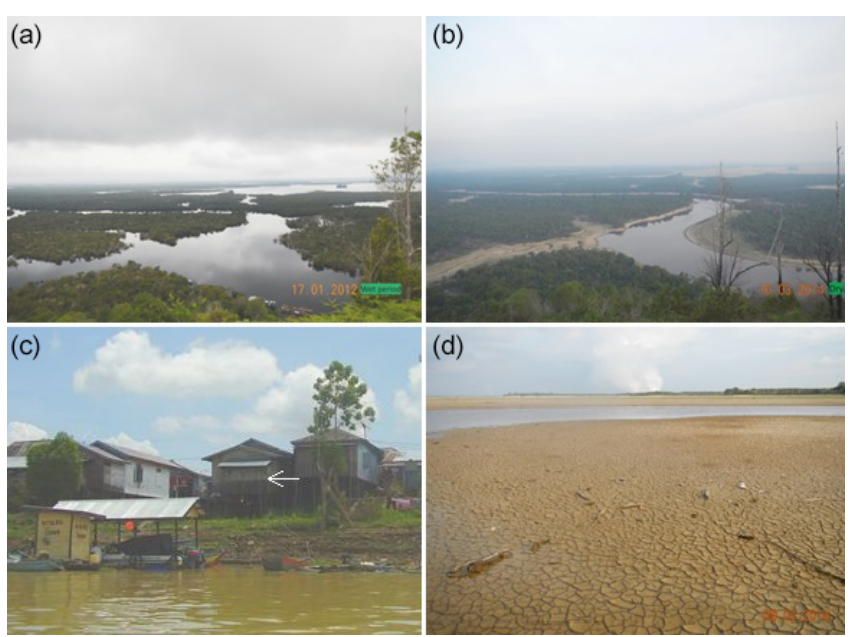

Figure 2. Photos from a wetland reconnaissance. (a) The Kapuas wetlands during the wet period showing full inundation and (b) during the dry period showing the exposed lake bed and the remaining wetted lake channel. (c) The Mahakam at the lake area; flood marks on trees and houses (white arrow) show the highest water level. (d) Another scene from a drought event in the Kapuas wetlands with forest/shrub fires in the background.

bouches into the Makassar Strait. Samarinda, the capital of East Kalimantan, which is inhabited by over 830000 people (estimate from 2014; see BPS-Samarinda, 2015), lies along the Mahakam just upstream of the delta region.

According to the Köppen climate classification, the climate of the region is tropical rainforest (Af type), which is characterised by a long-term mean precipitation higher than $60 \mathrm{~mm}$ in the driest month. The regional climate of Kaliman$\tan$ is generally influenced by the Indo-Australian monsoon driven by the Intertropical Convergence Zone (ITCZ) and ElNiño - Southern Oscillation (ENSO) phenomena (Meehl and Arblaster, 1998; Seidel et al., 2008). The central and northern parts of Kalimantan have bimodal rainfall patterns with two peaks of rainfall (generally from October to November and March to April) due to the global circulation and the regional climate (Aldrian and Susanto, 2003). The development of ElNiño in the Pacific, indicated by an anomalously cold sea surface temperature (SST), surrounds Indonesia. Warm anomalies develop in the eastern Pacific and western Indian Ocean (Hendon, 2003), generally triggering drought conditions in the region. Conversely, the development of a La Niña event indicated by SST anomalies in contrast to those during an El-Niño event results in increased rainfall during the dry season. However, the ENSO effect in Indonesia is not uniform throughout the seasons. Rainfall anomalies tend to persist in the dry season but not in the wet season (Hendon, 2003). 


\section{Methodology}

Field data described in this contribution were obtained during fieldwork campaigns in Mahakam held in 2008-2009 and in the Kapuas held in 2013-2015. Details on field data used in this study are presented in Table 1. Point measurements of rainfall were conducted using rain gauges and automatic weather stations. The Tropical Rainfall Measuring Mission (TRMM) rainfall estimates were acquired from the NASA's Goddard Earth Sciences Data and Information Services Center Interactive Online Visualization and Analysis Infrastructure (Giovanni) at http://giovanni.gsfc.nasa.gov/. We used the TRMM daily 3B42 and monthly 3B 43 rainfall products in this study. The daily TRMM rainfall rate was used to show the spatial rainfall variability in the study area and to be compared with previous studies (Wuis, 2014; Tekelenburg, 2014) with a short period of observation (about 2 months). The monthly TRMM rainfall rate was presented along with the publicly available SOI index, which has monthly values. A comprehensive description of the TRMM rainfall products, which have been available since 1998, can be found in Huffman et al. (2007). Water levels were measured using pressure transducers, while soil moisture sensors were used to estimate the volumetric soil moisture contents. Water levels of lakes were measured at the shore, resulting in an unmeasured water column of the deeper region. Therefore, a depth of $1 \mathrm{~m}$ was added to the water levels for water volume estimation, based on bathymetry measurements. Discharges were estimated from measurements using horizontal acoustic Doppler current profilers (H-ADCP) deployed in middle Mahakam at Melak, which is upstream of the Mahakam wetland region about $300 \mathrm{~km}$ from the river mouth (Hidayat et al., 2011b) and in the middle Kapuas at Sanggau, which is situated about $270 \mathrm{~km}$ from the river mouth (Kastner et al., 2015). The discharge data from H-ADCP measurements were in half-hourly time step that enable us to see the hysteretic behaviour of discharge as a result of backwater effects. To establish water discharge through the river section, boat surveys were carried out at the cross sections where the H-ADCP was deployed.

The Sanggau flow monitoring station is located downstream of the Kapuas wetland region. Therefore, to evaluate the water surface profile and flow from this discharge station upstream through the Kapuas wetlands region, a onedimensional hydraulic representation of the river was made in HEC-RAS (US Army Corps of Engineers, 2002), an open software river analysis system developed by the US Hydrological Engineering Centre. Two of the HEC-RAS components were used: the steady flow surface water computations (to determine average water profiles and levels for minimum and maximum discharges) and the unsteady flow simulation (to simulate one-dimensional unsteady flow through a full network of open channels). Upstream of the Kapuas and the Melawi River (the southern tributary) a flow hydrograph was given as the boundary condition, based on characteristics of the upstream subcatchment that drains directly into the Kapuas River. At the downstream end of the river, a rating curve function obtained from the stage-discharge relation at Sanggau was provided as the boundary condition. We used a constant Manning roughness coefficient $n$ of 0.035 , which corresponds to a normal river channel with some weeds and stones for the entire Kapuas and Melawi reaches. A spatial discretization of $3 \mathrm{~km}$ and a time step of 20 min were chosen for this model. Spatial resolution of $3 \mathrm{~km}$ is considered sufficient for the modelled river section of $553 \mathrm{~km}$ from Putussibau to Sanggau. Regarding time resolution, flow velocity and cross-sectional distance show that the resolution in time cannot exceed $25 \mathrm{~min}$. Models runs showed that the model is stable for $\delta t<20 \mathrm{~min}$. For $\delta t$ equal to $30 \mathrm{~min}$, the model was conditionally stable, and it is unstable for $\delta t>1 \mathrm{~h}$. The difference between model outcomes on a 20 min resolution vs. a $1 \mathrm{~min}$ resolution was negligible. Model evaluation was carried out using the Nash-Sutcliffe (NS) efficiency coefficient:

$\mathrm{NSE}=1-\frac{\Sigma_{t=1}^{T}\left[Q_{\mathrm{obs}}(t)-Q_{\mathrm{sim}}(t)\right]^{2}}{\Sigma_{t=1}^{T}\left[Q_{\mathrm{obs}}(t)-\bar{Q}_{\mathrm{obs}}\right]^{2}}$,

where $Q_{\mathrm{obs}}(t)$ and $Q_{\mathrm{sim}}(t)$ correspond to observed and calculated discharge at time $t, \bar{Q}_{\text {obs }}$ is the average observed discharge, and $T$ is the total number of time steps. The NS coefficient for water level simulation was calculated in the same way by exchanging $Q$ with $h$.

Our HEC-RAS model was not entirely calibrated: literature values were used for parameters which were not measured. Uncertainty in model parameters can have an effect on the model outcomes. Therefore, effects of changes in lateral influx, lake water storage and Manning's roughness coefficient $(n)$ were investigated (Table 2). Water stage and discharge at Sanggau station and lake water level data were used to validate HEC-RAS model simulations. An increase in lateral fluxes leads to an increase in peak flow, lake level fluctuation and river stage fluctuation. An increase in storage vs. elevation relation decreases the lake water depths, but increases the outflow as the lake contains more water with the same elevation. A decrease in $n$, a decrease in bottom friction, leads to faster and larger discharges; the discharge at Sanggau increases. The associated river stages over the entire river profile are lower, as water discharges faster. Wetland water stages are also lower when Manning's $n$ decreases. Table 2 also shows that an increase in NS in the discharge simulation at Sanggau is associated with a decrease in NS of the stage simulation at Sanggau for all scenarios. Figure 3 shows the simulated and measured water levels of the Kapuas lake. The Kapuas wetland was modelled as one large reservoir. In fact, it is a complex system of seasonally connected small lakes and peatland that may cause discrepancies in magnitude and timing of changes in the water levels of the lake. Our model simulation reflects the bimodality of the rainfall pattern in the study area, as shown in the simulated discharge (Fig. 4). 
Table 1. Description of collected field data.

\begin{tabular}{llll}
\hline Measurement station & Location & Period of data & Variable measured \\
\hline Mahakam & & & \\
Rain-gauge at Melintang & $116.2563^{\circ} \mathrm{E} ; 0.3016^{\circ} \mathrm{S}$ & May 2008-Mar 2009 & rainfall, air temperature \\
Pressure transduser at Melintang & $116.2585^{\circ} \mathrm{E} ; 0.2932^{\circ} \mathrm{S}$ & Feb 2008-May 2009 & groundwater level \\
Pressure transduser at Jempang & $116.1884^{\circ} \mathrm{E} ; 0.4959^{\circ} \mathrm{S}$ & Mar 2008-May 2009 & lake level \\
H-ADCP discharge station at Melak & $115.8684^{\circ} \mathrm{E} ; 0.2998^{\circ} \mathrm{S}$ & Mar 2008-Aug 2009 & $\begin{array}{l}\text { water flow velocity, water level, } \\
\text { local bathymetry }\end{array}$ \\
& & & \\
Kapuas & & & \\
Automatic weather station at Leboyan & $112.2909^{\circ} \mathrm{E} ; 1.0830^{\circ} \mathrm{N}$ & Dec 2013-Mar 2015 & rainfall, air temperature \\
Pressure transduser at Leboyan & $112.3094^{\circ} \mathrm{E} ; 1.0876^{\circ} \mathrm{N}$ & Dec 2013-Mar 2015 & groundwater level \\
Pressure transduser at Sentarum & $112.0636^{\circ} \mathrm{E} ; 0.8388^{\circ} \mathrm{N}$ & Mar 2014-Mar 2015 & lake level \\
Soil moisture sensor at Leboyan & $112.2909^{\circ} \mathrm{E} ; 1.0830^{\circ} \mathrm{N}$ & Dec 2013-Feb 2014 & soil moisture content \\
H-ADCP discharge station at Sanggau & $110.5889^{\circ} \mathrm{E} ; 0.1149^{\circ} \mathrm{N}$ & Oct 2013-Apr 2015 & water flow velocity, water level, \\
& & & local bathymetry \\
\hline
\end{tabular}

Table 2. Effects of changing lateral influx (Q1) $\left[\mathrm{m}^{3} \mathrm{~s}^{-1}\right]$, lake storage/elevation $(L)[\mathrm{m}]$ and Manning's $n\left[\mathrm{~s} \mathrm{~m}^{-1 / 3}\right]$ on simulated water level $(h)$ and discharge $(Q)$ at Sanggau.

\begin{tabular}{llr}
\hline Scenario & NS $Q$ Sanggau & NS $h$ Sanggau \\
\hline Q1 1.1 & 0.81 & 0.09 \\
Q1 0.9 & 0.87 & 0.77 \\
$L 1.1$ & 0.88 & 0.59 \\
$L 0.9$ & 0.88 & 0.50 \\
$n 0.03$ & 0.89 & 0.48 \\
$n 0.03$ & 0.87 & 0.53 \\
\hline
\end{tabular}

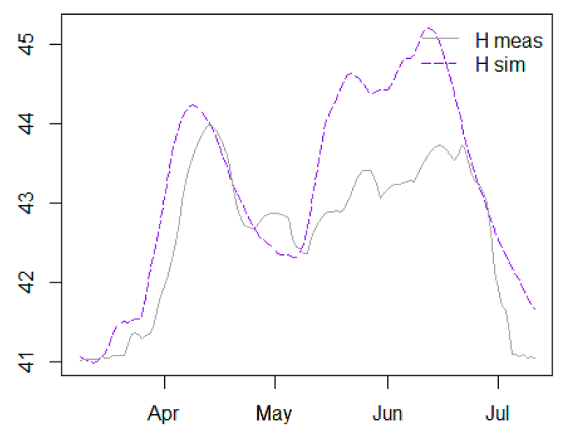

Figure 3. Simulated (dashed line) and measured (solid line) water levels (metres above sea level) of the Kapuas lake.

Inundation maps were obtained from the analysis of PALSAR images available for the period 2007-2010. Flood occurrences were mapped following the method for flood mapping of open water and flooding under vegetation (Hidayat et al., 2012). Crucial in this method is the onset of backscatter for open water (upper threshold) and for inundation under vegetation cover (the lower threshold). To determine threshold values for open water flood occurrence mapping, radar backscatter statistics of regions covering the main river and lakes known to be permanently inundated were taken. The
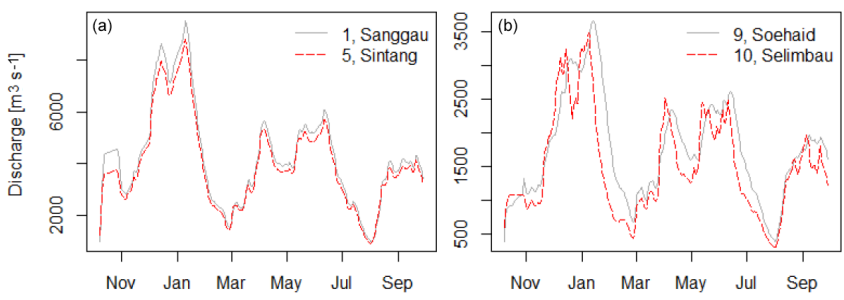

Figure 4. HEC-RAS simulated discharges for different cross sections in the downstream Kapuas River (a) and the upstream Kapuas River (b) of the modelled river section.

mean plus 1 standard deviation was chosen as the upper threshold for inundation as open water. For inundation under vegetation, the mean value of radar backscatter sampled from floodplain regions known to be frequently flooded was taken as the lower threshold. Open water inundation occurrence has an accuracy of about $85 \%$ while the reported accuracy of inundation occurrence under vegetation is $78 \%$ (Hidayat et al., 2012). From inundation area and lake water levels, we roughly estimated the total volume of water in the lake regions. Areas of floodplain lakes are following the seasonal inundation pattern as a result of variable rainfall rates. The period of Mahakam water level measurements coincided with part of the PALSAR data acquisition dates. Therefore, we were able to derive a lake depth $(h)$ - area $(A)$ relationship that was used to estimate the lakes' water levels beyond the period of our measurements (Fig. 5). For the Kapuas, our water level measurement did not coincide with the PALSAR observation period. With an assumption of uniform distribution of depths, we develop a depth-rainfall relationship. Correlation analysis reveals that the depth of the lakes is well correlated with the two-month moving average of areal rainfall $\left(P_{2 \mathrm{~m}}\right)$. We obtained a linear depth-rainfall relation that was applied to approximate water levels of the Kapuas lakes, 


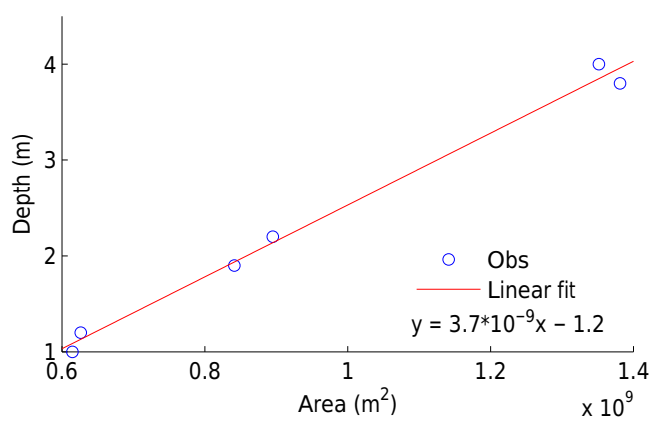

Figure 5. Relationship between measured depth of the middle Mahakam lakes and area of open water inundation from PALSAR images.

reading

$h=0.021 \cdot P_{2 \mathrm{~m}}-2.4$.

For a drought study in the two basins, we simulated the transient water balance (Van Lanen et al., 2013) using rainfall estimates from TRMM and potential evapotranspiration from the Climate Research Unit (CRU) (Harris et al., 2014) as input data to derive groundwater recharge for the period from 1998 to 2014. The spatial resolution of the gridded potential evapotranspiration obtained from CRU is $0.5^{\circ}$. Our measured data were used to validate the TRMM product. Therefore, the difference in the period of field campaigns in the Kapuas and Mahakam basins has little effect on the overall results. Different land uses were used simulate the actual evapotranspiration in the wetland area and were identified from the Borneo land-use and land cover map (Hoekman et al., 2010). Drought events are derived from time series of groundwater recharge using the threshold level approach. This approach defines drought as a period in which the recharge is below a certain threshold value (Hisdal et al., 2004). As in previous studies (e.g. Sheffield and Wood, 2008; Tallaksen et al., 2009; Van Lanen et al., 2013), we applied the 80 percentile from the duration curve as a threshold. We applied monthly variable thresholds that were identical for both river basins, which were derived from the Mahakam basin, being the driest. Drought duration is considered as the period from the start to the end of an uninterrupted drought.

\section{Hydrological characterisation}

\subsection{Climate and climate variability}

Rainfall rates are generally higher in the Kapuas than in the Mahakam. The spatial distribution of rainfall as TRMM daily rainfall rate $(\mathrm{mm})$ averaged over January 1998 December 2014 is shown in Fig. 6. The lowest average rainfall rate of about $5 \mathrm{~mm}_{\text {day }}{ }^{-1}$ was found in the Mahakam wetland region, while the highest rainfall rate of about
$11 \mathrm{~mm} \mathrm{day}^{-1}$ was found in the upper Kapuas region. As the spatial resolution of the TRMM data is very rough, smallscale variation cannot be observed. Spatial variability of rainfall is obvious in a subcatchment-scale daily field observation. Wuis (2014) and Tekelenburg (2014) reported that most high intensity showers in Bika, a subcatchment in the upper Kapuas region, can differ quite significantly over a short distance. Due to this large variation, rain gauges will have a small representative area. As TRMM measures the total rainfall over an area of $0.25^{\circ} \times 0.25^{\circ}$, the measured amounts are expected to represent the average rainfall over that area. The 17-year record of TRMM rainfall estimates confirms the rainfall pattern over the Kapuas and the Mahakam catchments to be bimodal with the average annual rainfall of approximately 3630 and $3000 \mathrm{~mm}$, respectively. Zoomed into the lowland areas, the Kapuas wetlands receives an average annual rainfall of $3700 \mathrm{~mm}$, while the Mahakam wetlands receives an average annual rainfall of $2690 \mathrm{~mm}$. The peak of rainfall usually occurs in December-January, with the second peak in March-April and the driest month is around JuneAugust. This pattern is always shifting backwards and forwards due to the ENSO influence.

The influence of ENSO in the region results in significant annual variation of rainfall. Rainfall is generally low in Indonesia during the warm period of ENSO and is indicated by a negative Southern Oscillation Index (SOI). The opposite trend occurs when the SOI is positive. Figure 7 shows the relationship between SOI and monthly rainfall depth in the Kapuas and Mahakam wetland regions (red boxes in Fig. 1) with correlation coefficients $(r)$ of 0.212 and 0.358 , respectively. This correlation, however, is not uniform throughout the season. For the Kapuas wetlands the highest $r$ value of 0.725 is found in August, while for the Mahakam wetlands the highest $r$ value of 0.732 is found in October. These $\mathrm{r}$ coefficient values show that the Mahakam wetland is more affected by the ENSO, which is also confirmed by its rainfall rate and drought duration described in the respective subsection. From the figure, an increasing trend in the peak of rainfall in the two catchments is also observed, while the trends of the mean and minimum rainfall are hardly detected from the available TRMM rainfall estimates.

Groundwater and soil moisture respond relatively quickly to rainfall events. Figure 8 (top panel) shows the increase/decrease of water level and soil moisture as the results of rainfall/no rainfall events at one of our monitoring stations in the upper Kapuas area. A similar result was found in the upper Kapuas peat-dominated Bika subcatchment as reported by Wuis (2014). This subcatchment is a fast-responding system characterised by shallow groundwater levels and rapid groundwater fluctuations; the increase in groundwater levels is clearly visible after precipitation events. Soil was saturated during the first period of our measurement in December-January, which is the peak period of rainfall (Fig. 7), followed by reasonably dry conditions in February that led to the drying-out of the lakes in the Kapuas 


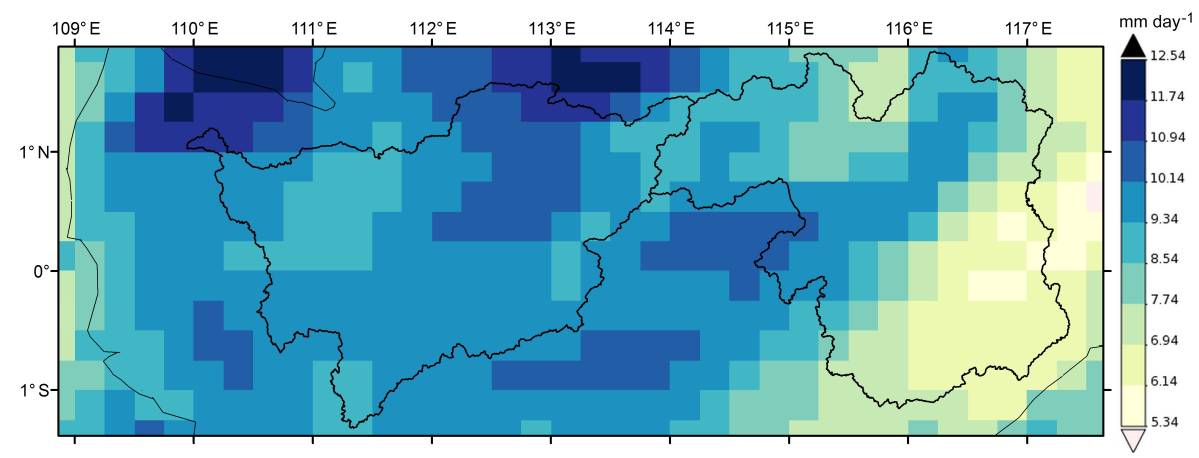

Figure 6. Spatial distribution of rainfall as TRMM daily rainfall rate (mm) averaged over January 1998-December 2014. Bold black lines indicate catchment boundaries and thin lines indicate approximate coast lines.

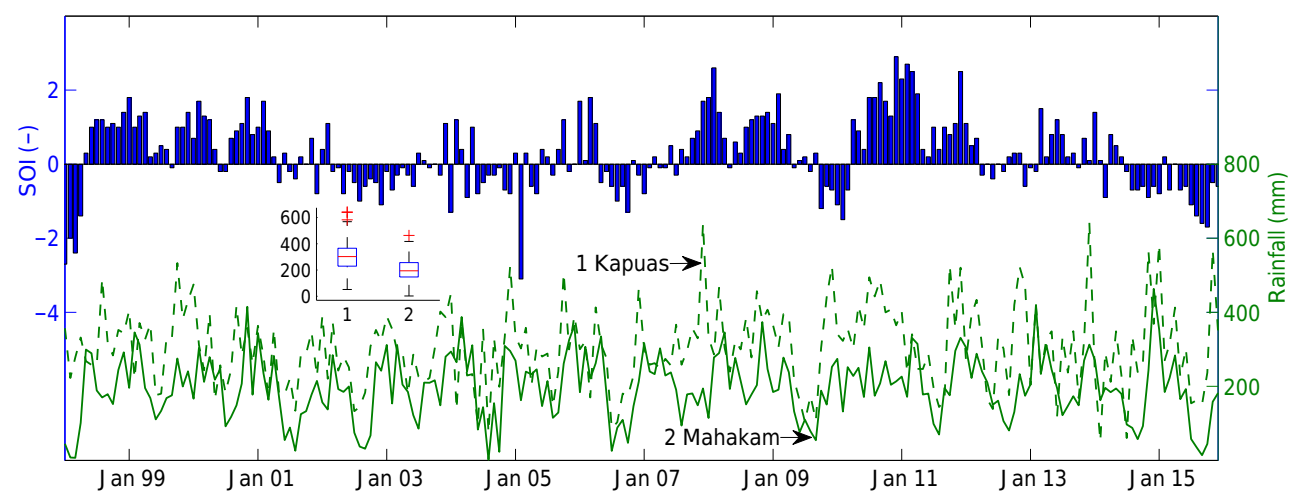

Figure 7. Monthly rainfall of the Kapuas (dashed line) and the Mahakam (continuous line) lowlands from January 1998 to December 2015 plotted along with the Southern Oscillation Index (bars). Box plots show the variability of monthly rainfall in the two lowland regions.

wetlands in March 2014 (Fig. 2, bottom right). Groundwater and soil moisture are well correlated. Although the location of measurements are about $5 \mathrm{~km}$ apart, soil moisture was measured in a mineral soil while groundwater level was measured in a peat soil. No soil moisture observation was carried out in the Mahakam. Figure 8 (bottom panel) shows hourly rainfall and groundwater level measured at a peat forest site next to Lake Melintang. During a normal period, groundwater level response to rainfall events is rather lenient due to the presence of the lake nearby. The response is slightly faster during dry conditions as the lake's water level is also low. As the Melintang peat forest is part of the Mahakam lowlands, groundwater level is not only a function of local rainfall but it is also influenced by upstream conditions. River bank overtopping upstream of the lake region causes a sudden increase in water level observed during the peak of the wet period.

\subsection{Streamflow and flood hydraulics}

Consistent with the local humid climate, the Kapuas and the Mahakam are rainfall driven rivers. Figure 9 shows discharge series of the Kapuas at Sanggau and the Mahakam at Melak flow monitoring stations. Hydrograph behaviour of the Kapuas at Sanggau and the Mahakam at Melak generally cor- responds to monthly average precipitation behaviour with a small delay in time. The Kapuas mean discharge at Sanggau is about $5000 \mathrm{~m}^{3} \mathrm{~s}^{-1}$, while that of the Mahakam at Melak is about $2000 \mathrm{~m}^{3} \mathrm{~s}^{-1}$. During low flows in July-August, both discharge time series show subdaily fluctuations, which correspond to tidal signals. Tidal energy can reach that far upstream because the terrain of the middle and lower regions of the Kapuas and that of the Mahakam are relatively flat.

The Kapuas flow monitoring station at Sanggau is located downstream of the wetlands area and lies in relatively steeper terrain that marks the transition between the middle and the lower Kapuas regions. This results in an almost unambiguous stage-discharge relation due to the absence of backwater effects. The opposite condition was observed in the discharge series from the Mahakam discharge station at Melak, which was located upstream of the wetlands area in a relatively mild topography. Variable backwater effects from floodplain impacts, lakes and tributaries and effects of river-tide interaction are apparent in the ambiguous stage-discharge relation. Water level fluctuations of about $10 \mathrm{~m}$ were recorded during our observation at Melak station. Discharge at this location is highly hysteretic, and is extensively discussed in Hidayat et al. (2011b). From water level records, they show that wet- 

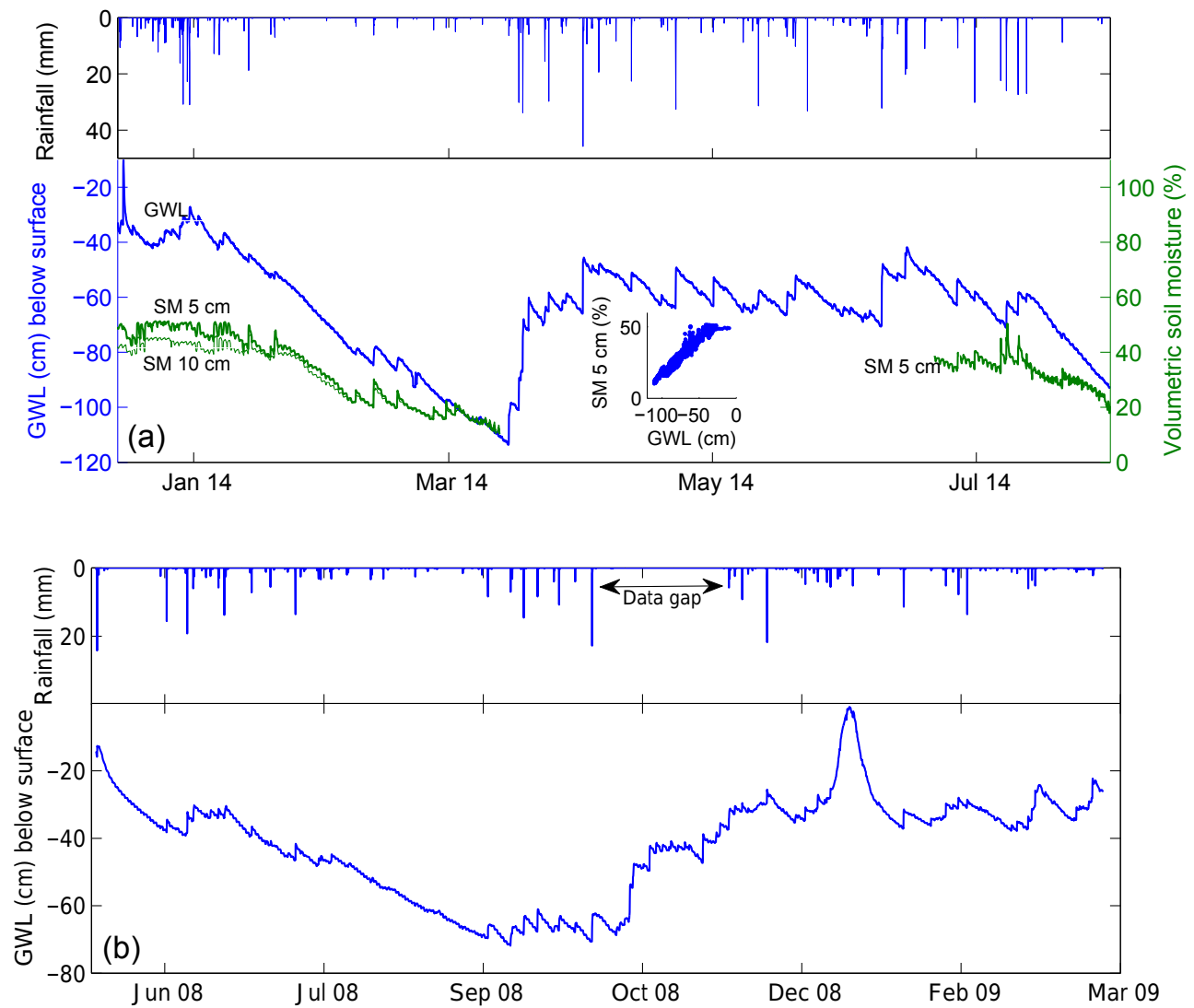

Figure 8. (a) Hourly groundwater level and surface level $(5 \mathrm{~cm}$ deep) and $10 \mathrm{~cm}$-deep soil moisture response as results of rainfall (and no rainfall) events in the Kapuas. The scatter plot shows the relation between soil moisture and groundwater level. Note that while rainfall and soil moisture were measured at the same location (mineral soil), groundwater level was measured about $5 \mathrm{~km}$ apart (peat soil). (b) Hourly rainfall and groundwater level of the Mahakam peat forest near Lake Melintang.
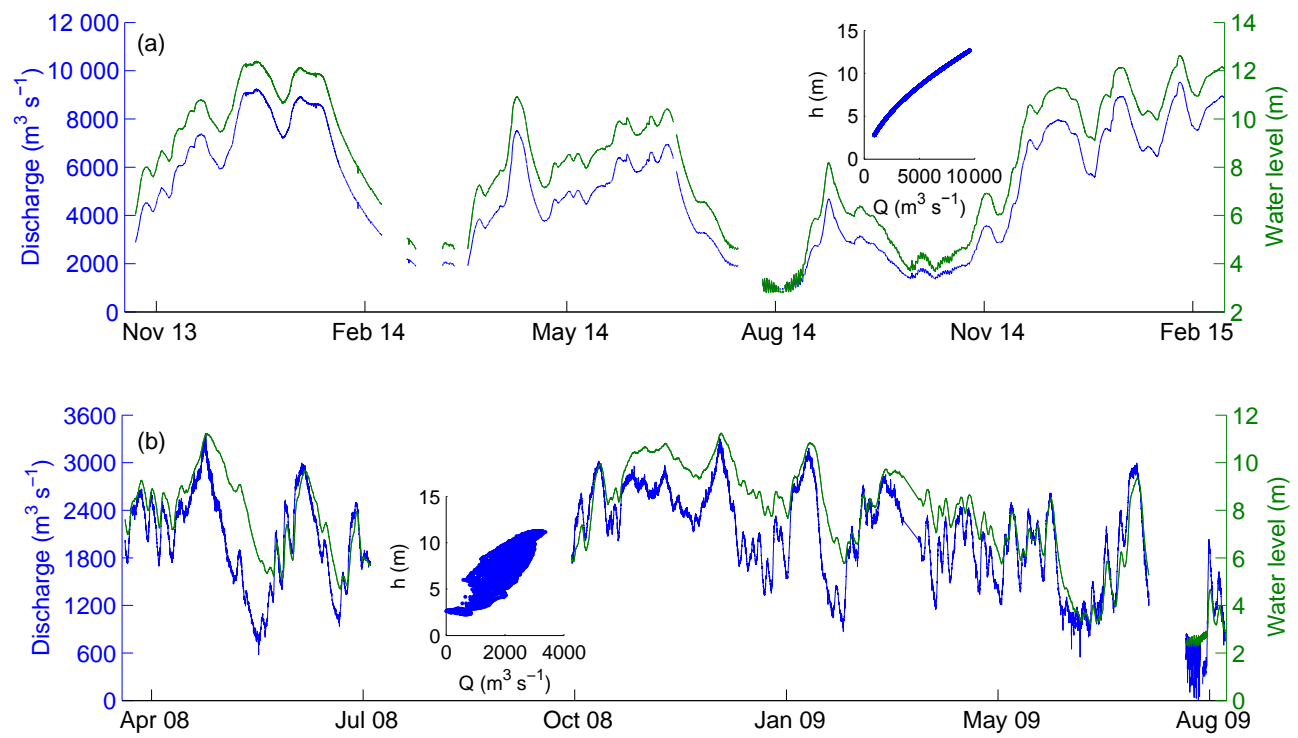

Figure 9. Discharge series from flow monitoring stations of the Kapuas at Sanggau (a) and the Mahakam at Melak (b) with scatter plots showing stage-discharge relations. Water stages are with respect to the pressure gauge positions. 

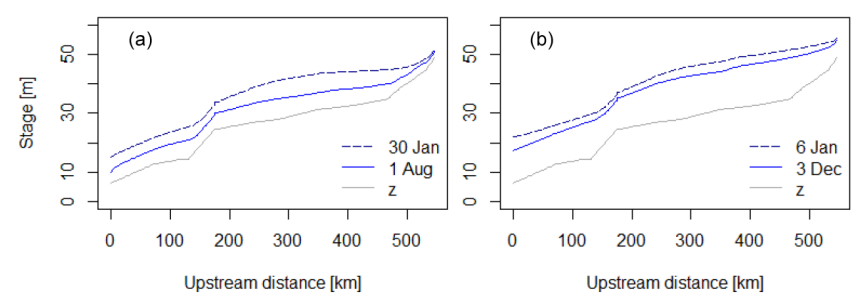

Figure 10. Longitudinal surface water profile over the Kapuas river reach from Sanggau to Putussibau; $z$ is bed elevation. (a) Water stages are plotted for 30 January and 1 August, displaying the falling limbs of the hydrograph. (b) The rising limbs, when the water levels are increasing, are shown for 3 December 2014 and 6 January 2015.

lands, including some 30 lakes in the middle Mahakam area, play a role in water level peak attenuation via a lake filling and emptying mechanism.

Water levels also fluctuated with a range of about $10 \mathrm{~m}$ at our discharge monitoring station of the Kapuas at Sanggau. No significant hysteresis occurs in the stage-discharge relation at this flow monitoring station. As it is the case of the middle Mahakam region, backwater effects are likely to occur upstream of the Kapuas wetlands area, which was investigated using the HEC-RAS river analysis system (Bol, 2015). Figure 10 (left) shows the falling limb of the hydrograph from the Kapuas HEC-RAS model simulation. When the water levels drop, a smooth surface water profile develops. In the upper half of the Kapuas a water hump is formed where the maximum water depth of $13.1 \mathrm{~m}$ occurs about $280 \mathrm{~km}$ upstream of Sanggau. The rising limb of the hydrograph is displayed in Fig. 10 (right). At about $350 \mathrm{~km}$ upstream of Sanggau, the Tawang channel meets the Kapuas, connecting the wetland to the river. Directly upstream of this wetland a backwater curve arises during the rising limb of the hydrograph. Wuis (2014) observed hysteresis loops in the stagedischarge relation of the Bika River, a tributary debouching to the Kapuas upstream of the wetland area. She found that, due to backwater effects from the main Kapuas as well as from ponding of the lower Bika region, low water levels can imply both a low and a high discharge, which also holds for high water levels.

\subsection{Inundation dynamics}

Both catchments are characterised by vast wetland areas. Figure 11 shows the inundation occurrence in the upper Kapuas and Mahakam lake area derived from 20 PALSAR images available in the period from 2007 to 2010. Estimates of the total volumes of the lakes in the Kapuas and the Mahakam lake area are shown in Fig. 12. As these estimates were derived without incorporating the lake's bathymetry, which is generally flat as shown on Fig. 2 (bottom right), the value presented herein should be merely considered a rough estimate of storage capacity. The highest estimated total volume of water in the Kapuas lakes is about 3 billion $\mathrm{m}^{3}$ during the PALSAR data acquisition on 8 April 2009, while that of the Mahakam lakes is about 6.5 billion $\mathrm{m}^{3}$ during the PALSAR data acquisition on 12 May 2010. Considering the extent of flooding under vegetation cover (Fig. 11), the maximum total volume of water stored in these wetlands could be twice as much as the abovementioned values. This partly explains why such a large discharge variation occurred at a given water stage as shown in the scatter plot of Fig. 9 (bottom panel) at the discharge station upstream of the wetland region.

\subsection{Drought occurrence and fire vulnerability}

Groundwater tables in the lowlands of Borneo are typically shallow; capillary rise from groundwater normally feeds soil water in the topsoil to (partially) compensate for the high evapotranspiration losses. Groundwater recharge reflects soil hydrological processes well, including capillary rise and evapotranspiration. During the dry season, low recharge is common and it can even become negative, meaning topsoil moisture is too low to compensate for the evapotranspiration flux and capillary rise occurs, which is not always enough to keep the evapotranspiration at the potential rate. The two lowlands under study show a different hydroclimatic regime. In the Kapuas, a high median monthly groundwater recharge $\left(161 \mathrm{~mm} \mathrm{month}^{-1}\right)$ occurs, which is twice as high that of Mahakam lowland (Fig. 13, left panel). The Kapuas lowlands have few periods with low groundwater recharge during the dry season. Prolonged drought is rarely found in the Kapuas (only few events last up to 3 months (Fig. 13, right panel). In contrast, the Mahakam wetland area regularly exhibits low groundwater recharges, which may lead to prolonged drought events that can last up to 13 months. It appears that the Mahakam lowland is more vulnerable to hydrological drought, leading to higher fire risk.

\section{Discussion}

Tropical rivers exhibit a fairly direct response to rainfall input with strong seasonality as a dominant feature (Syvitski et al., 2014). This is also the case in the Kapuas catchment, which generally reacts very quickly and behaves as a straightforward system. In a lowland region, the presence of wetlands locally averts the river system from this general principle. Our HEC-RAS model simulations shows that lakes and adjacent wetlands have a delaying effect on river discharges and diminish water levels and flow fluctuations. The average lake level fluctuation of $7.3 \mathrm{~m}$ for the entire wetland area is in the same range as previously documented ranges of 8 and $11 \mathrm{~m}$ (Klepper et al., 1996; Anshari et al., 2004). During the rising limb of the hydrograph, as could be seen in Fig. 9, a backwater curve arises just upstream of the Tawang channel, which connects the lake area to the Kapuas. Next to discharge, backwater influences river flow velocities, which 

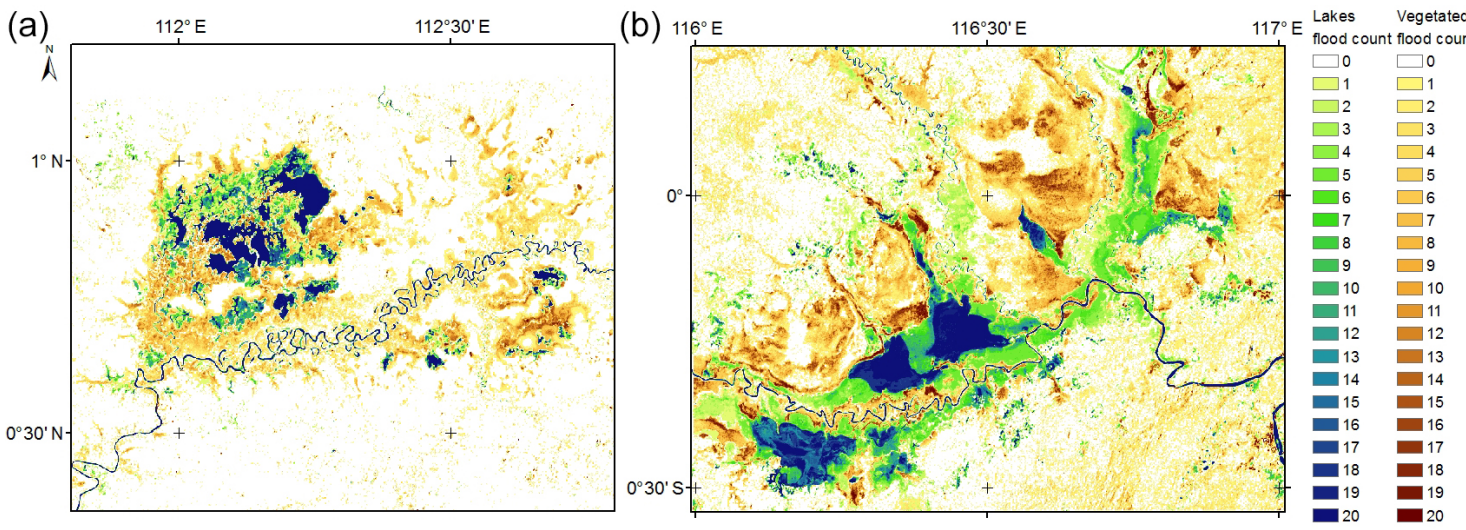

Figure 11. Inundation occurrence in the upper Kapuas (a) and Mahakam (b) lake area derived from 20 PALSAR images of 2007-2010 as open water (light green - dark blue) and flooding under vegetation (light - dark brown). Vertical legend on the right: Lake flood count in open water; vegetated flood count in flooding under vegetation.
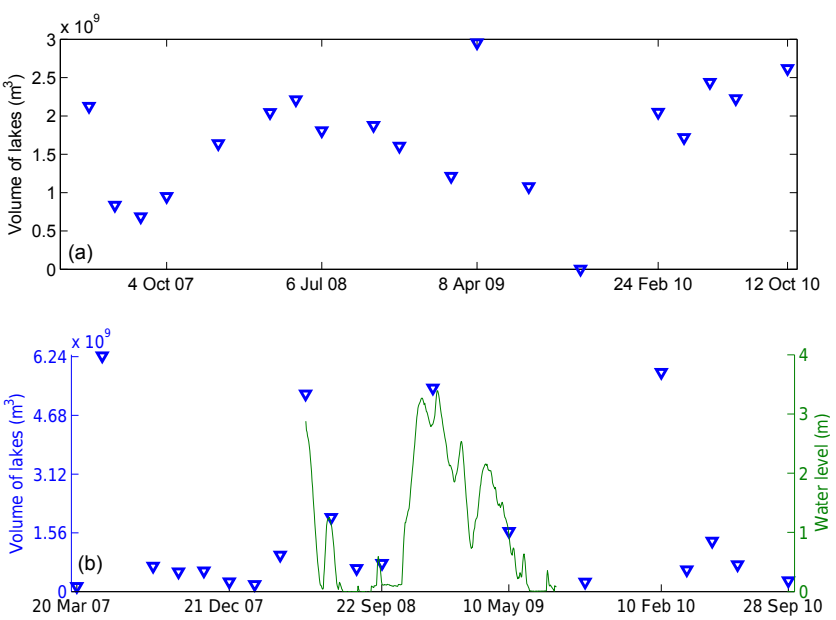

Figure 12. Estimates of total volume of lakes in the Kapuas (a) and the Mahakam (b) lowlands derived from flooded pixel areas in PALSAR images. Note that stream network was not removed during the flood count assessment, which renders the area of inundation somewhat overestimated.

is an important factor in river meander growth. From an analysis using a series of Landsat images, Huisman (2014) found a clear transition between a more active channel migration of the Kapuas upstream of the lake area and a less active migration downstream. The border between these two regimes was found $10 \mathrm{~km}$ upstream of the Tawang channel. At this border, a clear transition between river flow velocities is observed. Erosion and transport of the eroded material can take place during bankfull discharge, while during low flows, when flow velocities fall below the settling velocity of sediment particles, sediments can be deposited. The distinct changes in flow velocities and the accelerating and decelerating behaviour could also explain why the Kapuas is very actively meandering in its upper reaches. During the rising
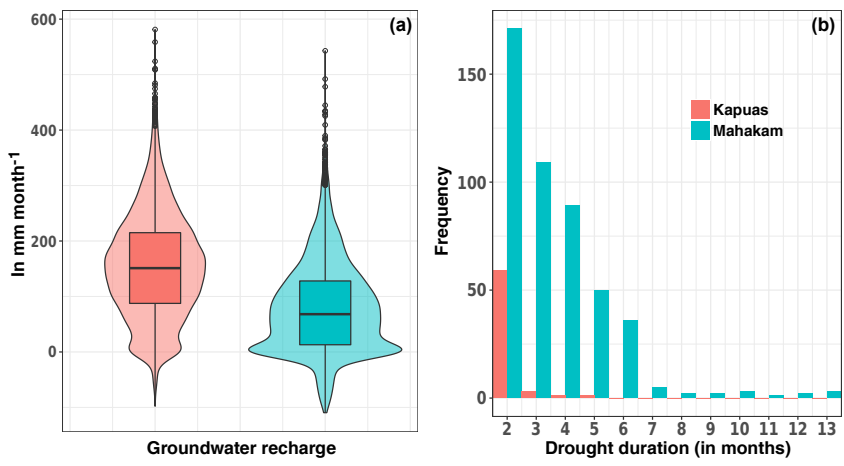

Figure 13. Hydroclimatological regimes and drought in the Kapuas and Mahakam lowlands: (a) violin and box plots showing the distribution of monthly groundwater recharge over the period of the TRMM data set (1998-2014); (b) drought in groundwater recharge showing different durations.

limb of the hydrograph no distinct effect of the wetland can be seen at the Sanggau discharge station. The peak flows occur at the same moment in time and the discharge rises with the same speed. During the falling limb, effects of the wetland can be seen. The falling limb occurs more gradually and the minimum flow changes due to the supply of water from the lake.

Next to the effect on the river discharges, the wetland also gave rise to a backwater curve, rising upstream of the Tawang channel. This backwater curve affects the flow velocities and can influence the meandering behaviour of the Kapuas river. Processes of lake filling and emptying contribute to accelerating and retarding the river flow velocity. Due to the backwater effect from the lake, when lake level is high, the stage upstream of the lake area is relatively high for a relatively low discharge. This effect is reduced when the lake level dropped and the discharge increased while the water level keeps decreasing, pending sufficiently high discharge that renders wa- 


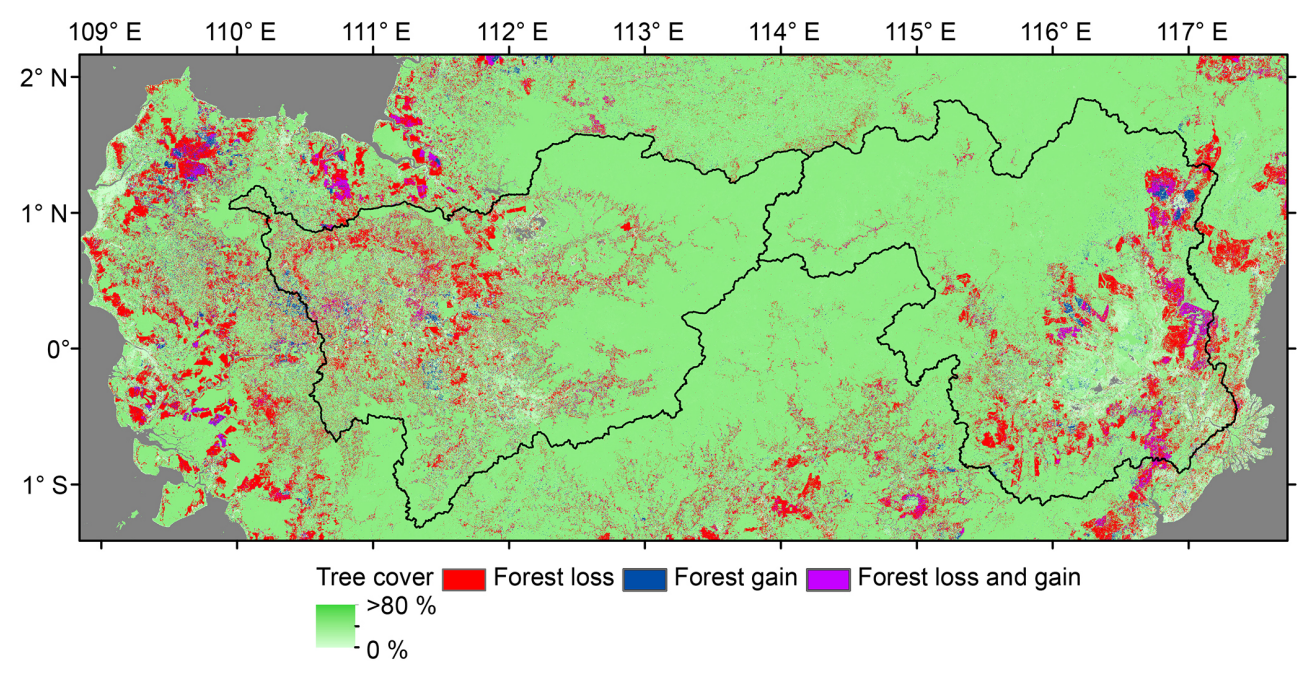

Figure 14. Tree cover (green) forest loss (red) forest gain (blue) with loss and gain (purple) between 2000-2012 in the Kapuas and the Mahakam. Data source: Global Forest Change (Hansen et al., 2013).

ter level to follow the discharge trend. During the lake-filling process, the contrasting mechanism took place. These mechanisms play a key role in regulating water level and discharge downstream (Hidayat, 2013). Vast areas of lowland wetlands in the middle Kapuas as well as in the middle Mahakam region form a massive water storage that eliminates sudden and large river discharge changes downstream. The moderation of discharge and water level fluctuations in the lower reaches of the river by the filling and emptying mechanisms of the lake, as shown by water level records as well as river-tide interactions, results in a relatively mild discharge variation in the downstream region (Hidayat et al., 2011b; Sassi and Hoitink, 2013).

The accurate, continuous discharge estimates from the H-ADCP allow for a discussion on the difference between runoff and discharge in the backwater affected region, in our case upstream of the wetland/lake regions. ADCP flow measurements are costly and time consuming. Nevertheless, there is no simple alternative to monitoring discharge dynamics in rivers with backwater. Too often, water agencies rely on rating curves that fail to capture the hysteresis effects. Hydrologists may not always be sufficiently critical about the accuracy of discharge estimates from rating curves. The data series presented in this contribution is relatively short, but we would like to point to the fact that regarding discharge data, long data series available elsewhere are always based on rating curve information, whereas our observations are made independent for discharge (using an H-ADCP) and water level. The rainfall data period is extended by the availability of TRMM products and potential evapotranspiration from CRU. Here we use data from 1998 to 2015. We concur that the analysis presented can be improved in the future, when longer data series are available, but the present data series are long enough to support the conclusions drawn. Further, the influence of ENSO on the Kapuas and Mahakam is not equally significant. This knowledge could be used to develop different consequences and policies.

The present study makes a systematic inventory of the existing studies of inland tropical lowlands, which have received relatively little attention, including gathering continuous flow data to accurately estimate river discharge, one of the key hydrological variables. Concerning discharge in the Kapuas, we are the first to record water discharge on the Kapuas River based on H-ADCP flow monitoring. Once a representative length of flow measurements is obtained, a model can be constructed to relate discharge data with other simpler to measure parameters such as stage, known as the rating curve technique. However, rating curves are subject to uncertainties concerning interpolation and extrapolation errors and seasonal plants variations (Di Baldassarre and Montanari, 2009) and may fail to capture discharge dynamics in lowland river reaches affected by backwater effects due to the inapplicability of the kinematic wave equation to handle the surface gradient term in the non-inertial wave equation (Hidayat et al., 2011b). A novel technique, such as neural networks, can be applied to model discharge in this hydrologically complex region. Hidayat et al. (2014) demonstrate that discharge in a tide-dominated river reach can be well modelled even without at-site stage records given that a representative discharge time series is available for training and validating the model. This implies that an H-ADCP can be installed temporarily in one location, e.g. 1 year of flow measurements, to obtain discharge estimates that can later on be used to train and validate the model. Once the model is established, it can be used for discharge prediction whilst the $\mathrm{H}-\mathrm{ADCP}$ can be installed in another location, optimising investment in monitoring instrumentation, even though a permanent H-ADCP station would be ideal. Similarly to that of 
the traditional rating curve technique, however, occasionally updating it with new data is required to adjust the neural network model to account for changes in the river system.

As radar is unrestricted by cloud cover, radar remote sensing technology presents an alternative to detecting changes in inundation states of wetlands in the humid tropics. From its dark signature, a fully inundated region can be easily recognised on radar images. From combining images produced by taking the minimum, mean and maximum backscatter values of radar images, a clear signature of flooding under vegetation can be obtained and from such images floodplain delineation can be performed (Hidayat et al., 2011a). The results presented herein provide a basis for a better understanding of the role of the Kapuas and the Mahakam inland wetlands, in buffering the discharge towards the downstream coastal regions. Radar-based floodplain observations may be used in future work to calibrate hydrodynamic models, simulating the filling and emptying processes of the lake area. This work has also contributed to the understanding of tropical lowlands. We find two important features, namely (1) widespread flooding and strong surface watergroundwater linkage and (2) strong backwater effects that form a dramatic multiple discharge hysteresis as shown in the $Q-h$ plot. We reveal the impacts of backwater effects, which proves the kinematic wave approach adopted in many hydrological studies unsuitable. These findings imply that many hydrological models will fail to describe the hydrology correctly if they do not account for the presence of standing water or high groundwater tables, and that many simple routing routines will fail to describe the discharge dynamics.

Climate extremes, both wet and dry, can have devastating impacts in tropical regions. Such impacts are well documented for the Amazon basin, but have received less attention for tropical rainforests in Asia, in particular those in Kalimantan. An exception forms the large-scale droughtinduced wildfires that have occurred over the past decades and which are associated with the El Niño Southern Oscillation (ENSO) phase (Siegert et al., 2001). Before the 1980s, it was believed that tropical rainforests were resilient to drought. During the 1982/1983 El Niño, it became clear that prolonged drought could cause large-scale damage to rainforests and peat soils due to widespread wildfires (Malingreau et al., 1985). Wildfires spread more easily due to an accumulation of leaf litter (van der Molen et al., 2011), which becomes extremely dry during drought conditions. This factor, along with those of anthropogenic origin; e.g. the conversion of forests to other land uses is the main contributor to loss of rainforest in Kalimantan's lowlands (Fig. 14). 72$85 \%$ of the middle Mahakam peatlands were burned between 1997 and 2000 (Chokkalingam et al., 2005). Fires mostly occurred within this period during the $1997 / 1998$ extremely dry El Niño-induced conditions. Another study by Siegert et al. (2001) reported that more than 2 million $\mathrm{Ha}$ of forest were burned in lowland Mahakam. At present, large-scale wildfires occur almost every year during the dry season, rais- ing the questions of whether climate variability and circulation changes can amplify anthropogenic land use changes, and how this will impact the hydrological functioning of the study area.

\section{Conclusions}

Alluvial floodplains of lowland rivers have become the centre of past and present human settlements due to their fertile soil which supports food production and easy access for transportation. With the ever-increasing water demands and threat from water-related disasters, hydrological prediction, on the one hand, is crucial to support a resilient society inhabiting the area. On the other hand, hydrological predictions in lowland rivers, especially in tropical regions, are difficult because of the scarcity of hydrometeorological data and flow regime complexity resulting from lake-river interactions, backwater and tidal effects, etc. This study offers a comprehensive view of the hydrological characteristics of two poorly gauged tropical inland lowland rivers: the Kapuas and the Mahakam in Kalimantan, Indonesia. Based on TRMM data, it was shown that both river basins experience strong seasonal fluctuations in precipitation. The Kapuas basin receives considerably more precipitation than the Mahakam. The Kapuas wetland area receives an average annual rainfall of $3700 \mathrm{~mm}$, while the Mahakam wetland area receives an average annual rainfall of $2690 \mathrm{~mm}$. In response to the strong seasonal variations in water input, both basins showed strong seasonal variability in inundation extent as derived from PALSAR images. The Kapuas and Mahakam lake regions are vast reservoirs of water that can store as much as 3 billion $\mathrm{m}^{3}$ and 6.5 billion $\mathrm{m}^{3}$ of water, respectively, which can be doubled when the area of flooding under vegetation cover is considered. We found the seasonally varying storage in both wetlands to exhibit an important role in regulating the discharge regime of the downstream parts of the rivers. Directly downstream of the wetland, the river discharges are most clearly affected. Based on discharge observations made by H-ADCP during dedicated field campaigns over multiple seasons, we found strong dynamics in both discharge and water levels. The seasonal amplitude in water levels was found to be around $10 \mathrm{~m}$ for both basins. Strong backwater effects in the Mahakam prohibited the use of a traditional rating curve for discharge estimation, calling into question the quality of historical discharge records in many lowland basins. Contrary to the moist nature of wetlands, the two lowlands are vulnerable to drought, especially during the warm period of ENSO, yet prolonged drought rarely occurs in the Kapuas under current climate conditions in line with observations of shallow groundwater tables and a strong coupling between groundwater and soil moisture observations. We found that the Mahakam lowland area is more vulnerable to hydrological drought, leading to the occurrence of fire. It is expected that the hydrological characterisations of the Kapuas and the 
Mahakam facilitates a better prediction of fire-prone conditions in these regions.

Our observations and analysis reveal a region dominated by highly dynamic hydrological processes, such as seasonal inundation over vast areas $\left(>1000 \mathrm{~km}^{2}\right)$, strong backwater effects, shallow groundwater tables and a high seasonal amplitude of river stages $(\sim 10 \mathrm{~m})$. Most of these processes are currently not or only crudely represented in hydrological models. We believe our study can contribute to the use of data from poorly gauged catchments to improve the next generation of models in areas that were traditionally a "blind spot" for model evaluation, but where strong changes in land use and climate provide an urgent need for better models.

Data availability. Data sets are provided in the Supplement.

\section{The Supplement related to this article is available online at doi:10.5194/hess-21-2579-2017-supplement.}

Competing interests. The authors declare that they have no conflict of interest.

Acknowledgements. This research has been funded by The Royal Netherlands Academy of Arts and Sciences (KNAW) through the Scientific Programme Indonesia-Netherlands SPIN3-JRP-29 and by the Netherlands Organization for Scientific Research (NWO grant number WT76-268). ALOS PALSAR data have been provided by JAXA EORC within the framework of the ALOS Kyoto and Carbon Initiative. TRMM data analysis and visualisation used in this paper were produced with the Giovanni online data system and developed and maintained by the NASA GES DISC. We thank the reviewers and the editor for their comments and suggestions, which helped to improve the manuscript.

Edited by: S. Uhlenbrook

Reviewed by: K. Hassaballah and M. C. Westhoff

\section{References}

Adam, E., Mutanga, O., and Rugege, D.: Multispectral and hyperspectral remote sensing for identification and mapping of wetland vegetation: a review, Wetl. Ecol. Manag., 18, 281-296, doi:10.1007/s11273-009-9169-z, 2010.

Aldrian, E. and Susanto, R. D.: Identification of three dominant rainfall regions within Indonesia and their relationship to sea surface temperature, Int. J. Climatol., 23, 1435-1452, doi:10.1002/joc.950, 2003.

Alsdorf, D., Beighley, E., Laraque, A., Lee, H., Tshimanga, R., Loughlin, F. O., Mahe, G., Dinga, B., Moukandi, G., and Spencer, R. G. M.: Opportunities for hydrologic research in the Congo Basin, Rev. Geophys., 54, 378-409, doi:10.1002/2016RG000517, 2016.
Anshari, G. Z., Kershaw, A. P., and van der Kaars, S.: A Late Pleistocene and Holocene pollen and charcoal record from peat swamp forest, Lake Sentarum Wildlife Reserve, West Kalimantan, Indonesia, Palaeogeogr. Palaeocol., 171, 213-228, doi:10.1016/S0031-0182(01)00246-2, 2001.

Anshari, G. Z., Kershaw, A. P., van der Kaars, S., and Jacobsen, G.: Environmental change and peatland forest dynamics in the lake sentarum area, West Kalimantan, Indonesia., J. Quaternary Sci., 19, 637-655, doi:10.1002/jqs.879, 2004.

Baird, A. J., Surridge, B. W. J., and Money, R. P.: An assessment of the piezometer method for measuring the hydraulic conductivity of a Cladium mariscus-Phragmites australis root mat in a Norfolk (UK) fen, Hydrol. Process., 18, 275-291, doi:10.1002/hyp.1375, 2004.

Bol, D.: The influence of the Upper Kapuas wetland area on the Kapuas flow characteristics, West-Kalimantan, Indonesia: A hydrological modelling study, Master's thesis, Wageningen University, 2015.

Bonnet, M. P., Barroux, G., Martinez, J. M., Seyler, F., MoreiraTurcq, P., Cochonneau, G., Melack, J. M., Boaventura, G., Maurice-Bourgoin, L., Leon, J. G., Roux, E., Calmant, S., Kosuth, P., Guyot, J. L., and Seyler, P.: Floodplain hydrology in an Amazon floodplain lake (Lago Grande de Curuai), J. Hydrol., 349, 18-30, 2008.

BPS-Kalbar: Kalimantan Barat In Figures, BPS-Statistics of Kalimantan Barat, available at: http://kalbar.bps.go.id/website/pdf_ publikasi/Kalimantan-Barat-Dalam-Angka-2015.pdf (last access: 25 October 2016), 2015.

BPS-Kaltim: Kalimantan Timur in Figures, BPSStatistics of Kalimantan Timur, available at: http: //kaltim.bps.go.id/webbeta/website/pdf_publikasi/

Kalimantan-Timur-Dalam-Angka-Tahun-2015.pdf (last access: 25 October 2016), 2015.

BPS-Samarinda: Statistik Daerah Kota Samarinda, Badan Pusat Statistik Kota Samarinda, available at: http: //samarindakota.bps.go.id/webbeta/website/pdf_publikasi/

Statistik-Daerah-Kota-Samarinda-2015.pdf (last access: 25 October 2016), 2015.

Brauer, C. C., Teuling, A. J., Torfs, P. J. J. F., and Uijlenhoet, R.: The Wageningen Lowland Runoff Simulator (WALRUS): a lumped rainfall-runoff model for catchments with shallow groundwater, Geosci. Model Dev., 7, 2313-2332, doi:10.5194/gmd-7-23132014, 2014.

Buschman, F. A., Hoitink, A. J. F., van der Vegt, M., and Hoekstra, P.: Subtidal water level variation controlled by river flow and tides, Water Resour. Res., 45, 1-12, doi:10.1029/2009WR008167, 2009.

Chokkalingam, U., Kurniawan, I., and Ruchiat, Y.: Fire, livelihoods, and environmental change in the Middle Mahakam peatlands, East Kalimantan, Ecology Society, 10, 1-17, 2005.

Cole, C. A., Brooks, R. R., and Wardrop, D. H.: Wetland hydrology as function of hydrogeomorphic (HGM) subclass, Wetlands, 17, 456-467, doi:10.1007/BF03161511, 1997.

Corzo, G. A., Solomatine, D. P., Hidayat, de Wit, M., Werner, M., Uhlenbrook, S., and Price, R. K.: Combining semi-distributed process-based and data-driven models in flow simulation: a case study of the Meuse river basin, Hydrol. Earth Syst. Sci., 13, 1619-1634, doi:10.5194/hess-13-1619-2009, 2009. 
Devito, K. J., Hillb, A. R., and Roulet, N.: Groundwater-surface water interactions in headwater forested wetlands of the Canadian Shield, J. Hydrol., 181, 127-147, 1996.

Di Baldassarre, G. and Montanari, A.: Uncertainty in river discharge observations: a quantitative analysis, Hydrol. Earth Syst. Sci., 13, 913-921, doi:10.5194/hess-13-913-2009, 2009.

Fraser, C. J. D., Roulet, N. T., and Lafleur, M.: Groundwater flow patterns in a large peatland, J. Hydrol., 246, 142-154, doi:10.1016/S0022-1694(01)00362-6, 2001.

Hansen, M. C., Potapov, P. V., Moore, R., Hancher, M., Turubanova, S. A., Tyukavina, A., Thau, D., Stehman, S. V., Goetz, S. J., Loveland, T. R., Kommareddy, A., Egorov, A., Chini, L., Justice, C. O., and Townshend, J. R. G.: High-resolution global maps of 21st-century forest cover change, Science, 342, 850-853, 2013.

Harris, I., Jones, P., Osborn, T., and Lister, D.: Updated high-resolution grids of monthly climatic observations the CRU TS3.10 Dataset, Int. J. Climatol., 34, 623-642, doi:10.1002/joc.3711., 2014.

Hendon, H. H.: Indonesian rainfall variability: impacts of ENSO and local air-sea interaction, J. Climate, 16, 1775-1790, 2003.

Herschy, R. W.: Streamflow Measurement, Taylor \& Francis, London and New York, third edn., 2009.

Hess, L. L., Melack, J. M., Affonso, A. G., Barbosa, C., GastilBuhl, M., and Novo, E. M. L. M.: Wetlands of the Lowland Amazon Basin: Extent, Vegetative Cover, and Dual-season Inundated Area as Mapped with JERS-1 Synthetic Aperture Radar, Wetlands, 35, 745-756, doi:10.1007/s13157-015-0666-y, 2015.

Hidayat: Runoff, discharge and flood occurrence in a poorly tropical basin: The Mahakam River, Kalimantan, PhD thesis, Wageningen University, 2013.

Hidayat, Hoekman, D. H., Vissers, M. A. M., and Hoitink, A. J. F.: Combining ALOS-PALSAR imagery with field water level measurements for flood mapping of a tropical floodplain, in: Proc. SPIE 8286, edited by: He, X., Xu, J., Ferreira, V. G., International Symposium on LIDAR and Radar Mapping: Technologies and Applications, Nanjing, China, doi:10.1117/12.912735, 2011a.

Hidayat, H., Vermeulen, B., Sassi, M. G., Torfs, P. J. J. F., and Hoitink, A. J. F.: Discharge estimation in a backwater affected meandering river, Hydrol. Earth Syst. Sci., 15, 2717-2728, doi:10.5194/hess-15-2717-2011, $2011 \mathrm{~b}$.

Hidayat, H., Hoekman, D. H., Vissers, M. A. M., and Hoitink, A. J. F.: Flood occurrence mapping of the middle Mahakam lowland area using satellite radar, Hydrol. Earth Syst. Sci., 16, 18051816, doi:10.5194/hess-16-1805-2012, 2012.

Hidayat, H., Hoitink, A. J. F., Sassi, M. G., and Torfs, P. J. J. F.: Prediction of Discharge in a Tidal River Using Artificial Neural Networks, J. Hydrol. Eng., 19, 04014006, doi:10.1061/(ASCE)HE.1943-5584.0000970, 2014.

Hisdal, H., Tallaksen, L. M., Clausen, B., Peters, E., and Gustard, A.: Hydrological drought processes and estimation methods for streamflow and groundwater, vol. 48, chap. Hydrological drought characteristics, 139-198, Dev. Water Sci., 2004.

Hoch, J. M., Haag, A. V., van Dam, A., Winsemius, H. C., van Beek, L. P. H., and Bierkens, M. F. P.: Assessing the impact of hydrodynamics on large-scale flood wave propagation - a case study for the Amazon Basin, Hydrol. Earth Syst. Sci., 21, 117-132, doi:10.5194/hess-21-117-2017, 2017.

Hoekman, D. H., Vissers, M. A. M., and Wielaard, N.: PALSAR Wide-area mapping of Borneo: methodology and valida- tion, IEEE J. Select. Topics Appl. Earth Obs. Remote Sensing, 3, 605-617, doi:10.1109/JSTARS.2010.2070059, 2010.

Hoitink, A. J. F. and Jay, D.: Tidal river dynamics: Implications for deltas, Rev. Geophys., 54, 1-33, doi:10.1002/2015RG000507, 2016.

Hoitink, A. J. F., Buschman, F. A., and Vermeulen, B.: Continuous measurements of discharge from a horizontal acoustic Doppler current profiler in a tidal river, Water Resour. Res, 45, 1-13, doi:10.1029/2009WR007791, 2009.

Huffman, G. J., Adler, R. F., Bolvin, D. T., Gu, G., Nelkin, E. J., Bowman, K. P., Yong, Y., Stocker, E. F., and Wolff, D. B.: The TRMM Multi-satellite Precipitation Analysis (TMPA): Quasiglobal, multi-year, combined-sensor precipitation at fine scales, J. Hydrometeor., 8, 38-55, doi:10.1175/JHM560.1, 2007.

Huisman, A.-K.: Observing river migration development from landsat images: application to the Kapuas River, Master's thesis, Wageningen University, 2014.

Ishii, Y., Koizumi, K., Fukami, H., Yamamoto, K., Takahashi, H., Limin, S. H., Kusin, K., Usup, A., and Susilo, G. E.: Tropical Peatland Ecosystems, chap. Groundwater in Peatland, 265-279, Springer, Japan, doi:10.1007/978-4-431-55681-7_17, 2015.

IUCN: Species of the Day: Irrawaddy Dolphin, Tech. rep., International Union for Conservation of Nature, available at: http://support.iucnredlist.org/sites/default/files/species_pdf/ orcaella-brevirostris.pdf, last access: 25 October 2016.

Kastner, K., Hoitink, A., Vermeulen, B., Hidayat, Sassi, M., Pramulya, M., and Ningsih, N.: Comparison of Discharge Estimates from a rating curve and ADCP measurements, in: E-proceedings of the 36th IAHR World Congress, The Hague, the Netherlands, available at: https://www.iahr.org/site/cms/contentDocumentLibraryView. asp? chapter $=42 \&$ category $=344 \&$ article $=1154$ (last access: 14 April 2016), 2015.

Klepper, O., Asmoro, P. B., and Suyatno, N.: A hydrological model of the danau sentarum floodplain lakes, Perspectives in Tropical Limnology, 267-275, available at: http://www.scopus. com/inward/record.url?eid=2-s2.0-0030513447\&partnerID= 40\&md5=38197c5dde05ae5a7fef4542fd2f569f (last access: 3 January 2012), 1996.

Lesack, L. F. W. and Melack, J. M.: Flooding hydrology and mixture dynamics of lake water derived from multiple sources in an Amazon floodplain lake, Water Resour. Res., 31, 329-345, 1995.

Loh, P. S., Chen, C.-T. A., Anshari, G. Z., Wang, J.-T., Lou, J.-Y., and Wang, S.-L.: A comprehensive survey of lignin geochemistry in the sedimentary organic matter along the Kapuas River (West Kalimantan, Indonesia), J. Asian Earth Sci., 43, 118-129, doi:10.1016/j.jseaes.2011.09.005, 2012.

MacKinnon, K., Hatta, G., Halim, H., and Mangalik, A.: The ecology of Indonesia series - The ecology of Kalimantan, Oxford University Press, 1996.

Malingreau, J., Stephens, G., and Fellows, L.: Remote Sensing of Forest Fires: Kalimantan and North Borneo in 1982-83, Ambio, 14, 314-321, 1985.

McGlynn, B. L., Blöschl, G., Borga, M., Bormann, H., Hurkmans, R., Komma, J., Nandagiri, L., Uijlenhoet, R., and Wagener, T.: Run-off Prediction in Ungauged Basins: Synthesis Across Processes, Places and Scales, chap. A data acquisition framework for predictions of runoff in ungauged basins, 29-51, Cambridge Univ. Press, 2013. 
Meehl, G. and Arblaster, J.: The Asian-Australian Monsoon and El Niño-Southern Oscillation in the NCAR Climate System Model, J. Climate, 11, 1356-1385, doi:10.1175/15200442(1998)011<1356:TAAMAE>2.0.CO;2, 1998.

Miguez-Macho, G. and Fan, Y.: The role of groundwater in the Amazon water cycle: 1. Influence on seasonal streamflow, flooding and wetlands, J. Geophys. Res., 117, D15113, doi:10.1029/2012JD017539, 2012.

Petersen-Overleir, A. and Reitan, T.: Bayesian analysis of stage-fall-discharge models for gauging stations affected by variable backwater, Hydrol. Process., 23, 3057-3074, doi:10.1002/hyp.7417, 2009.

Qi, S., Brown, D. G., Tian, Q., Jiang, L., Zhao, T., and Bergen, K. M.: Inundation extent and flood frequency mapping using LANDSAT imagery and digital elevation models, GISci. Remote Sens., 46, 101-127, doi:10.2747/1548-1603.46.1.101, 2009.

Ran, L. and Lu, X. X.: Delineation of reservoirs using remote sensing and their storage estimate: an example of the Yellow River Basin, China, Hydrol. Proc., 26, 1215-1229, doi:10.1002/hyp.8224, 2012.

Rautner, M., Hardiono, M., and Alfred, R. J.: Borneo: Treasure Island at Risk, WWF Germany, Frankfurt am Main, available at: http://assets.panda.org/downloads/treasureislandatrisk. pdf (last access: 25 October 2016), 2005.

Sassi, M. G. and Hoitink, A. J. F.: River flow controls on tides and tide-mean water level profiles in a tidal freshwater river, J. Geophys. Res.-Oceans, 118, 4139-4151, doi:10.1002/jgrc.20297, 2013.

Sassi, M. G., Hoitink, A. J. F., Vermeulen, B., and Hidayat: Discharge estimation from H-ADCP measurements in a tidal river subject to sidewall effects and a mobile bed, Water Resour. Res., 47, 1-14, doi:10.1029/2010WR009972, 2011.

Schmalz, B., Tavares, F., and Fohrer, N.: Modelling hydrological processes in mesoscale lowland river basins with SWAT - capabilities and challenges, Hydrol. Sci. J., 53, 989-1000, doi:10.1623/hysj.53.5.989, 2008.

Seidel, D. J., Fu, Q., Randel, W. J., and Reichler, T. J.: Widening of the tropical belt in a changing climate, Nature Geosci., 1, 21-24, doi:10.1038/ngeo.2007.38, 2008.

Sheffield, J. and Wood, E. F.: Global trends and variability in soil moisture and drought characteristics, 1950-2000, from observation-driven simulations of the terrestrial hydrologic cycle, J. Climate, 21, 432-458, doi:10.1175/2007JCLI1822.1, 2008.

Siegert, F., Ruecker, G., Hinrichs, A., and Hoffmann, A. A.: Increased damage from fires in logged forests during droughts caused by El Nino, Nature, 414, 437-440, doi:10.1038/35106547, 2001

Sivapalan, M., Takeuchi, K., Franks, S. W., Gupta, V. K., Karambiri, H., Lakshmi, V., Liang, X., Mcdonnell, J. J., Mendiondo, E. M., O'connell, P. E., Oki, T., Pomeroy, J. W., Schertzer, D., Uhlenbrook, S., and Zehe, E.: IAHS decade on Predictions in Ungauged Basins (PUB), 2003-2012: Shaping an exciting future for the hydrological sciences, Hydrol. Sci. J., 48, 857-880, 2003.
Syvitski, J. P. M., Cohen, S., Kettner, A. J., and Brakenridge, G. R.: How important and different are tropical river? - an overview, Geomorphology, 227, 5-17, doi:10.1016/j.geomorph.2014.02.029, 2014.

Tallaksen, L., Hisdal, H., and van Lanen, H.: Space-time modelling of catchment scale drought characteristics, J. Hydrol., 375, 363372, doi:10.1016/j.jhydrol.2009.06.032, 2009.

Tekelenburg, X.: Hydrological dynamics of a tropical subcatchment of the Kapuas River, West Kalimantan, Indonesia, Master's thesis, Wageningen University, 2014.

US Army Corps of Engineers: HEC-RAS river analysis system, hydraulic reference manual, Report CPD-69., Hydraulic Engineering Center, Davis, 2002.

Van Bemmelen, R. W.: The Geology of Indonesia, vol. I A, Government Printing Office, The Hague, 1949.

van der Molen, M., Dolman, A., Ciais, P., Eglin, T., Gobron, N., Law, B., Meir, P., Peters, W., Phillips, O. L., Reichstein, M., Chen, T., Dekker, S. C., Doubkova, M., Friedl, M. A., Jung, M., den Hurk, B. J. V., de Jeu, R. A., Kruijt, B., Ohta, T., Rebel, K., Plummer, S. E., Seneviratne, S. I., Sitch, S., Teuling, A. J., der Werf, G. V., and Wang, G.: Drought and ecosystem carbon cycling, Agric. For. Meteorol., 151, 765-773, doi:10.1016/j.agrformet.2011.01.018, 2011.

Van Lanen, H. A. J., Wanders, N., Tallaksen, L. M., and Van Loon, A. F.: Hydrological drought across the world: impact of climate and physical catchment structure, Hydrol. Earth Syst. Sci., 17, 1715-1732, doi:10.5194/hess-17-1715-2013, 2013.

Van Loon, A. F., Van Huijgevoort, M. H. J., and Van Lanen, H. A. J.: Evaluation of drought propagation in an ensemble mean of large-scale hydrological models, Hydrol. Earth Syst. Sci., 16, 4057-4078, doi:10.5194/hess-16-4057-2012, 2012.

Verhoeven, J. T. A. and Setter, T. L.: Agricultural use of wetlands: opportunities and limitations, Ann. Bot., 105, 155-163, doi:10.1093/aob/mcp172, 2010.

Walsh, R.: Drought frequency changes in Sabah and adjacent parts of northern Borneo since the late nineteenth century and possible implications for tropical rain forest dynamics, J. Trop. Ecol., 12, 385-407, doi:10.1017/S0266467400009585, 1996.

Weedon, G. P., Gomes, S., Viterbo, P., Shuttleworth, W. J., Blyth, E., O., sterle, H., Adam, J. C., Bellouin, N., Boucher, O., and Best, M.: Creation of the WATCH Forcing Data and its use to assess global and regional reference crop evaporation over land during the twentieth century, J. Hydrometeorol., 12, 823-848, doi:10.1175/2011JHM1369.1, 2011.

Wuis, M.: Hydro(geo)logical flow characteristics of the Bika catchment, a subcatchment of the Kapuas River, Indonesia: A reconnaissance study, Master's thesis, Wageningen University, 2014.

Zedler, J. B. and Kercher, S.: Wetland resource: Status, trends, ecosystem services, and restorabilitys, Annu. Rev. Environ. Resour., 30, 39-74, doi:10.1146/annurev.energy.30.050504.144248, 2005. 